\title{
Impact of Plant Clinics on Farmers' Knowledge, Attitude and Practice With Plant Health Issues
}

\author{
Raj K. Adhikari ${ }^{1, a, *}$, Punya P. Regmi ${ }^{1, b}$, Resham B. Thapa ${ }^{1, c}$, Yubak Dhoj G.C ${ }^{2, d}$, Eric Boa Boa $^{3, e}$ \\ ${ }^{1}$ Institute of Agriculture and Animal Science, Tribhuvan University, Nepal \\ ${ }^{2}$ Ministry of Agriculture and Livestock Development, Nepal \\ ${ }^{3}$ University of Aberdeen, $U K$
}

${ }^{*}$ Corresponding author

A R T I C L E I N F O
Research Article
Received : 04/02/2018
Accepted : 03/08/2019

A B S T R A C T

Plant clinics in Nepal has been started in 2008 and has coverage in more than 40 districts of Nepal. A study has been conducted in Chitwan district of Nepal to assess the changes on farmer's knowledge attitude and practice due to implementation of plant clinics. Total of 175 clinic attendants and 175 non-attendants were selected by simple random sampling method and interviewed by using semi-structured questionnaire. By and large, this study found wider positive changes among clinic attendants than non-attendants especially on their knowledge and skills to identity pests and diseases with their causes and practice appropriate remedial measures against those problems. The study revealed positive impact to by increasing knowledge and skillset among attending farmers to assess the season of disease and pest occurrence, estimate economic threshold level as well as preventive

Keywords:

Plant Clinic

Knowledge

Attitude and curative measures against the plant health problems. Plant clinic has made impressive positive changes on adoption of recommended dose of pesticides and organic control methods among Practice (KAP) attendants than non-attendants. The level of awareness and adoption of waiting period after pesticide Difference in Difference (DiD)

rajkadhikari@gmail.com profrbthapa@gmail.com e eric_boa@hotmail.com

\author{
(D) https://orcid.org/0000-0003-3736-8688 \\ iD https://orcid.org /0000-0002-5303-4850 \\ (iD) https://orcid.org/0000-0002-9044-2093
}

b@ punyaregmi@gmail.com d@yubakgc@yahoo.com https://orcid.org/0000-0002-2371-6947 iD https://orcid.org/0000-0001-8153-4175

\section{(c) (1) () T) This work is licensed under Creative Commons Attribution 4.0 International License}

\section{Introduction}

Agriculture in Nepal has a long history but it received institutionalized extension services only since 1950 s (K.C. et al., 2003). Currently, District Agriculture Development Office (DADO) and its Agricultural Service Center (ASC) are major public service units for overall agricultural extension services in Nepal including plant protection. Plant Protection Directorate (PPD) provides technical backup to the DADOs and ASCs on plant protection related matters. But the public extension staff to farming household ratio is 1:164 (Adhikari et al., 2013) that clearly indicates limited access to extension services for the farming community. The limited access and the quality of advisory services is directly related to the knowledge and skill of farmers to take care the plant health problems leading to poor yield (Oerke, 2006), decreased quality of produce (European Commission, 2005; Kroschel et al., 2009) and pesticides hazards (Atreya, 2005; Shrestha and Neupane, 2002).
The concept of plant clinic has developed to provide plant health care service to farmers (Bentley et al., 2007; Boa, 2009) as complement to existing agriculture extension services. It run by local plant protection expert or extension staffs called as plant doctor (Bentley et al., 2007) who are specially trained to diagnose the plant health problems and provide advice to farmers on healthcare for their plants (Danielsen and Kelly, 2010). This concept was introduced in Nepal in 2008 (Adhikari, 2009; Boa and Harling, 2008) and is being practiced by different government and non-government organizations (Adhikari et al., 2015, 2016, 2013). It promotes integrated pest and crop management approaches based on bottom up approach to respond the demands from farmers, rather than to the needs defined by extension workers or researchers. Different studies has emphasized positive impact of plant clinics on increased access to quality services, increased yield, income and increased adoption of eco-friendly 
practices (Danielsen and Fernandez, 2008; Kelly et al., 2008; Negussie et al., 2011; Srivastava, 2013; Vakilian, 2017) but similar studies are very scanty in Nepal. Therefore, this study was conducted to see the effectiveness of plant clinics on change in farmers Knowledge, attitude and practices.

\section{Methodology}

The farm output depends on the appropriateness of the technology adopted and physical input use that in turn depends on existing knowledge, attitude and practices of the farmers. A farmer chooses various management practices to meet their objectives, based on their knowledge, belief and attitude on any farming technology. Knowledge, Attitude and Practice (KAP) analysis is common in anthropological and behavioral studies including agriculture due to its easy design, quantifiable data, ease of implementation and concise presentation of results and wider applicability (Launiala, 2009). It helps to identify knowledge gaps, behavioral patterns, and beliefs and understanding of issues during its baseline or impact assessment (Bhurtyal et al., 2016; Ngowi et al., 2002) and design or modify any extension projects for increased participation, adoption of technology and increased performance. It has been used in numerous studies related to plant health and pesticide uses (Janhong et al., 2005; Jors et al., 2014; WHO, 2008).

This study was carried out in Chitwan district of Nepal, purposively selected because of the clinic operation from initial periods (Adhikari, 2012) and availability of clinic information to frame the study population and sample. The list of plant clinic attendants mentioned in plant clinic register was taken as study population from which 175 farmers were randomly selected as study sample. Similarly, equal number of farmers who didn't attend any clinics were selected from same locality as the control group for impact assessment (Bamberger et al., 2004). Pretested semi-structured questionnaire was used to collect primary information from the sampled farmers. The questionnaire includes both the qualitative and quantitative variables on a wide range of knowledge, attitude and practices related to the plant health problems. Thus collected data were coded, entered into the computer and analyzed using Microsoft Excel and Statistical Package for Social Sciences (SPSS) version 20. The changes in KAP before and after the clinics were analyzed by adopting Difference in Difference (DiD) model as appropriate method for impact assessments (Bertrand et al., 2004; Chen et al., 2006; Ravallion, 2005; Sarma et al., 2016; Verner and Verner, 2013). The DiD method used in this study is illustrated in table 1 below, where the outcomes of two different points ( $\mathrm{T} 1$ and $\mathrm{T} 2$ ) for the clinic attendants were compared with the non-attendants for the same time points.

Table 1 Difference in difference (DiD) model

\begin{tabular}{l|ccc}
\multicolumn{1}{c|}{ C } & Before Clinics & After Clinics & Difference \\
\hline PH & $\mathrm{X}_{\mathrm{t} 1}$ & $\mathrm{X}_{\mathrm{t} 2}$ & $\mathrm{D}_{1}=\left(\mathrm{X}_{\mathrm{t} 2}-\mathrm{X}_{\mathrm{t} 1}\right)$ \\
$\mathrm{NPH}$ & $\mathrm{Y}_{\mathrm{t} 1}$ & $\mathrm{Y}_{\mathrm{t} 2}$ & $\mathrm{D}_{2}=\left(\mathrm{Y}_{\mathrm{t} 2}-\mathrm{Y}_{\mathrm{t} 1}\right)$ \\
$\mathrm{D}$ & $\mathrm{D}_{2}=\left(\mathrm{X}_{\mathrm{t} 1}-\mathrm{Y}_{\mathrm{t} 1}\right)$ & $\mathrm{D}_{1}=\left(\mathrm{X}_{\mathrm{t} 2}-\mathrm{Y}_{\mathrm{t} 2}\right)$ & $\mathrm{DiD}=\mathrm{D}_{1}-\mathrm{D}_{2}$ \\
\hline
\end{tabular}

C: Category, PH: Participating households, NPH: Non-participating households, D: Difference, Adapted from Gertler et al. (2011)

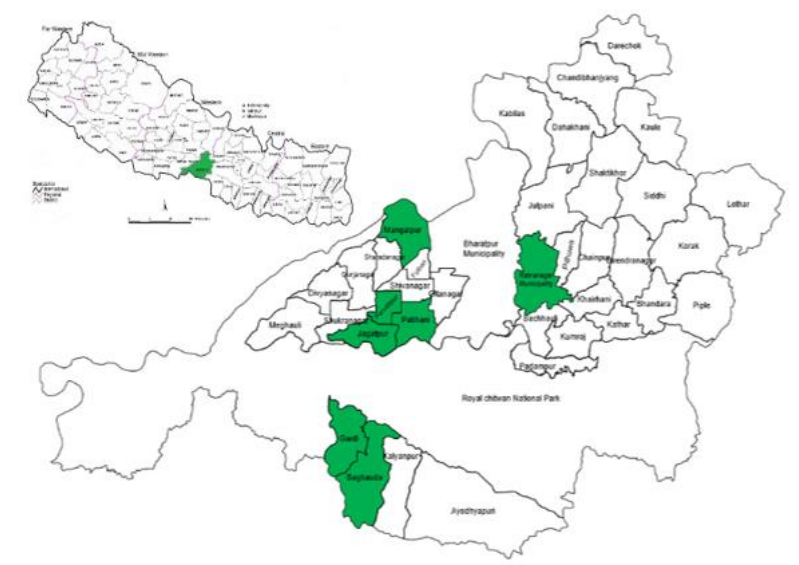

Figure 1 Map of Nepal highlighting study district and sites

\section{Result and Discussion}

\section{Socio-economic Description of Respondents}

The average household size of the respondents was significantly higher among attendants (5.11) then nonattendants (4.58) which is quite above the Chitwan district average of 4.5 (CBS, 2014). Majority of the attendants $(60.06 \%)$ were male while majority of non-attending respondents $(58.3 \%)$ were female. This indicates the limited access and exposure of females farmers to external environment and resources including access to information that is also supported by earlier studies (Cornhiel, 2006; Gartaula et al., 2010; Maharjan et al., 2012; Miiro et al., 2015; Rajendran and Islam, 2017). The study found $10.9 \%$ of attendants and $25.1 \%$ non-attendants were still illiterate with average of $18 \%$ in total. This resembles with district status of 23.02 illiteracy (CBS, 2014). The proportion of farmers attending secondary level (6-10 ${ }^{\text {th }}$ grade) education was found highest in both categories.

\section{Figures in Parenthesis Indicate the Percentage}

The average land holding of the surveyed household was 0.48 ha only with range of 0.10 ha to 3.87 ha. It was found significantly higher ( $0.54 \mathrm{ha}$ ) among attendants than the non-attendants $(0.43 \mathrm{ha})$. Results of present study revealed that $72 \%$ of the total responding household are affiliated with farmer's organization such as groups or cooperatives. Comparatively, $84 \%$ of the attendants and $60 \%$ of non-attendants were member of farmers' organization. On the other hand, only $48.9 \%$ of the total respondents had participated in at least one training on agriculture wherein $64 \%$ among attendants and only $33.7 \%$ among non-attendants were found to be trained.

\section{Knowledge on Insect, Pest and Disease Identification}

Every extension project envies positive changes on knowledge and skill among its beneficiaries. This study found revealed the clear impact of plant clinic on farmers' knowledge and skills to identify pest and disease (Table 3). Farmers' knowledge on disease and insect pest identification among both categories of the farmers was found to be increased over the time but the increment was distinctly higher among clinic attendants. Table 3 shows the proportion of farmers with different level of knowledge and skill both before and after the clinics and the marginal 
change. The incremental proportion of respondents able to identify more than 5 types of diseases, 5 types of harmful insects and 5 types of beneficial insects was found to be higher among attendants by $6.9 \%, 5.2 \%$ and $9.7 \%$ respectively. None of the attendants were found unable to identify a single disease or pest after the clinic but still $3.4 \%$ and $4.6 \%$ of the non-attendants were unable to do so. The study result revealed that the plant clinics has changed the farmer's knowledge and skill to identify more number of diseases and insect pests.

Table 2 Socio-demographic characteristics of respondents

\begin{tabular}{|c|c|c|c|c|}
\hline \multirow{2}{*}{\multicolumn{2}{|c|}{ Parameter }} & \multicolumn{2}{|c|}{ Category of Respondent } & \multirow{2}{*}{ Total } \\
\hline & & Attendant & Non-Attendant & \\
\hline \multirow{2}{*}{ Gender } & Female & $69(39.4)$ & $102(58.3)$ & $190(48.9)$ \\
\hline & Male & $106(60.6)$ & $73(41.7)$ & $160(51.1)$ \\
\hline Household size & Mean number & $5.11 \pm 1.518$ & $4.58 \pm 1.573$ & $\begin{array}{c}\text { t-statistics }=3.216 \\
\text { p-value }=0.001\end{array}$ \\
\hline \multirow{5}{*}{ Occupation } & Agriculture & $139(79.4)$ & $119(68.0)$ & $258(73.7)$ \\
\hline & Business & $6(3.4)$ & $14(8.0)$ & $20(5.7)$ \\
\hline & Service & $20(11.4)$ & $24(14.3)$ & $45(12.9)$ \\
\hline & Student & $3(1.7)$ & $5(2.9)$ & $8(2.3)$ \\
\hline & Foreign employment & $7(4.0)$ & $12(6.9)$ & $19(5.4)$ \\
\hline \multirow{6}{*}{ Education } & Illiterate & $19(10.9)$ & $44(25.1)$ & $63(18.0)$ \\
\hline & Informal & $32(18.3)$ & $24(13.7)$ & $56(16.0)$ \\
\hline & Up to 5 grade & $26(14.9)$ & $22(12.6)$ & $48(13.7)$ \\
\hline & 6 to 10 grade & $66(37.7)$ & $51(29.1)$ & $117(33.4)$ \\
\hline & Intermediate & $21(12.0)$ & $20(11.4)$ & $41(11.7)$ \\
\hline & University & $11(6.3)$ & $14(8.0)$ & $21(7.1)$ \\
\hline Land holding & Hectare (Ha) & $0.54 \pm .518$ & $0.43 \pm .240$ & $\begin{array}{c}\text { t-statistics }=2.406 \\
\text { p-value }=0.017\end{array}$ \\
\hline \multirow{2}{*}{$\begin{array}{l}\text { Participation to } \\
\text { farmers organization }\end{array}$} & Yes & $147(84.0)$ & $105(60.0)$ & $252(72.0)$ \\
\hline & No & $28(16.0)$ & $70(40.0)$ & $98(28.0)$ \\
\hline \multirow{2}{*}{$\begin{array}{l}\text { Participation in } \\
\text { Trainings }\end{array}$} & Yes & $112(64.0)$ & $59(33.7)$ & $171(48.9)$ \\
\hline & No & $63(36.0)$ & $116(66.3)$ & $179(51.1)$ \\
\hline
\end{tabular}

Table 3 Change in knowledge on disease and insect pest identification

\begin{tabular}{|c|c|c|c|c|c|c|c|c|}
\hline \multirow{3}{*}{ KAP Parameters } & & \multicolumn{6}{|c|}{ Percentage of farmers by category } & \multirow{3}{*}{$\begin{array}{c}\text { Difference in } \\
\text { Difference (DiD) }\end{array}$} \\
\hline & & \multicolumn{3}{|c|}{ Attendant } & \multicolumn{3}{|c|}{ Non-Attendant } & \\
\hline & & Before & After & Difference & Before & After & Difference & \\
\hline \multirow{4}{*}{$\begin{array}{l}\text { Number of diseases } \\
\text { able to identify }\end{array}$} & 0 & 10.9 & 0.0 & -10.9 & 14.9 & 3.4 & -11.5 & -0.6 \\
\hline & $1-2$ & 66.3 & 32.0 & -34.7 & 81.1 & 60.0 & -21.1 & 13.6 \\
\hline & $3-5$ & 21.1 & 58.3 & 37.2 & 4.0 & 35.4 & 31.4 & 5.8 \\
\hline & $>5$ & 1.7 & 9.7 & 8.0 & 0.0 & 1.1 & 1.1 & 6.9 \\
\hline \multirow{4}{*}{$\begin{array}{l}\text { Number of harmful } \\
\text { pests able to identify }\end{array}$} & 0 & 8.6 & 0.0 & -8.6 & 17.7 & 4.6 & -13.1 & -4.5 \\
\hline & $1-2$ & 63.4 & 16.6 & -46.8 & 65.7 & 56.0 & -9.7 & 37.1 \\
\hline & $3-5$ & 24.6 & 69.7 & 45.1 & 16.6 & 34.3 & 17.7 & 10.8 \\
\hline & $>5$ & 3.4 & 13.7 & 10.3 & 0.0 & 5.1 & 5.1 & 5.2 \\
\hline \multirow{4}{*}{$\begin{array}{l}\text { Number of beneficial } \\
\text { insects able to } \\
\text { identify }\end{array}$} & 0 & 21.1 & 0.0 & -21.1 & 48.0 & 34.9 & -13.1 & 8 \\
\hline & $1-2$ & 64.6 & 26.3 & -38.3 & 47.4 & 44.0 & -3.4 & 34.9 \\
\hline & $3-5$ & 14.3 & 62.3 & 48 & 4.0 & 18.9 & 14.9 & 33.1 \\
\hline & $>5$ & 0.0 & 11.4 & 11.4 & 0.6 & 2.3 & 1.7 & 9.7 \\
\hline
\end{tabular}

Knowledge of Cause and Remedies

Farmers' knowledge on cause of disease and pest and their seasonality will help them to prepare for preventive or curative measures. Effective control of the plant health problems are dependent upon early and accurate diagnosis of the cause and appropriate response measures (Stack et al., 2014). The study found positive changes in knowledge on season of disease, pest occurrence among attendant farmers than non-attendant farmers. On the other hand, this study revealed that plant clinic has impact to increase the accuracy of knowledge and skills to identify the cause of plant health problems notably higher among the attendants than non-attendants. The study revealed that the plant clinic has made changes in farmer's knowledge and skill economic threshold level of pest diseases which is presented in Table 3. The changes in proportion of respondent with knowledge and confidence on economic threshold was found to be higher among clinic attendants than non-attendants. The study found about $41 \%$ progress among clinic attendant while only $20 \%$ among nonattendants. 
Table 4 Accuracy of knowledge on cause of plant health problem

\begin{tabular}{|c|c|c|c|c|c|c|c|c|}
\hline \multirow{2}{*}{\multicolumn{2}{|c|}{ KAP Parameters }} & \multicolumn{6}{|c|}{ Percentage of farmers by category } & \multirow[b]{2}{*}{$\begin{array}{c}\text { Difference in } \\
\text { Difference (DiD) }\end{array}$} \\
\hline & & \multicolumn{3}{|c|}{ Attendant } & \multicolumn{3}{|c|}{ Non-Attendant } & \\
\hline \multicolumn{2}{|c|}{$\begin{array}{l}\text { Know how on season of } \\
\text { disease and pest }\end{array}$} & 52.6 & 84.0 & 31.4 & 48.6 & 68.6 & 20 & 11.4 \\
\hline \multirow{4}{*}{$\begin{array}{l}\text { Accuracy of } \\
\text { knowledge on cause } \\
\text { of problem }\end{array}$} & Never & 34.3 & 5.1 & -29.2 & 36.6 & 16.0 & -20.6 & -8.6 \\
\hline & Rarely & 53.1 & 44.0 & -9.1 & 50.3 & 59.4 & 9.1 & -18.2 \\
\hline & Mostly & 11.4 & 44.6 & 33.2 & 13.1 & 24.0 & 10.9 & 22.3 \\
\hline & Always & 1.1 & 6.3 & 5.2 & 0.0 & 0.6 & 0.6 & 4.6 \\
\hline \multicolumn{2}{|c|}{$\begin{array}{l}\text { Knowledge on economic } \\
\text { threshold level }\end{array}$} & 30.9 & 71.4 & 40.5 & 28.6 & 48.6 & 20 & 20.5 \\
\hline \multicolumn{2}{|c|}{$\begin{array}{l}\text { Knowledge on preventive } \\
\text { Measures }\end{array}$} & 20.6 & 88.6 & 68 & 13.1 & 50.3 & 37.2 & 30.8 \\
\hline \multicolumn{2}{|c|}{$\begin{array}{l}\text { Knowledge on curative } \\
\text { measures }\end{array}$} & 25.7 & 86.9 & 61.2 & 25.1 & 60.0 & 34.9 & 26.3 \\
\hline
\end{tabular}

Table 5 Comparison of herbicide and pesticide application by category of farmers

\begin{tabular}{l|ccc|ccc}
\hline \multirow{2}{*}{ Category } & \multicolumn{3}{c|}{ Amount of herbicides $(\mathrm{Kg} / \mathrm{ha})$} & \multicolumn{3}{c}{ Amount of chemical pesticides $(\mathrm{Kg} / \mathrm{ha})$} \\
\cline { 2 - 7 } & Before & After & Difference & Before & After & Difference \\
\hline Attendant & 0.37 & 0.04 & $-0.33^{*}$ & 0.41 & 0.64 & $0.23^{*}$ \\
Non-Attendant & 0.31 & 0.43 & $0.11^{*}$ & 0.47 & 0.58 & 0.11 \\
Difference & 0.05 & $-0.39^{*}$ & $-0.44^{*}$ & -0.06 & 0.06 & 0.12 \\
\hline
\end{tabular}

* significant at $99 \% \mathrm{CI}$, ** significant at $95 \% \mathrm{CI}$, *** significant at $90 \% \mathrm{CI}$

The principle of 'prevention is better than cure' always fits even in plant health issues too. Therefore, farmers' knowledge on preventive and curative measures against the major disease were discussed in this study too. The study finding shows the wider positive increment on proportion of attending farmers than non-attending farmers knowledgeable on preventive and curative measures against the plant health problems. The number of additional farmers familiar on preventive measures was found to be $68 \%$ among clinic attending category while only $37.2 \%$ among non-attending. Similarly, $61.2 \%$ additional farmers participating in clinics were found to be aware on curative measures while only $34.9 \%$ additional farmers from non-attending category were found familiar on curative measures. Similar study done in Bangladesh revealed that $100 \%$ of plant clinic users felt their ability to quickly identify crop problems had increased compared to $16 \%$ of non-users (Rajendran and Islam, 2017). These figures clearly address the impact of plant clinics on farmers' knowledge and skill on preventative and curative measures of plant health care.

\section{Pesticides Use}

Pesticides and herbicides are major agrochemicals used by farmers to control different crop pests and weeds. Quality advisory services has impact on farmers knowledge and practice the appropriate use of agrochemicals.. This study found the decrease in herbicide use but increase in pesticide use by farmers. Table 5 compares the difference dose of herbicide and pesticide application by category of farmers at two time points. The average dose of herbicides used by clinic attendants was found insignificantly higher $(0.37 \mathrm{~kg} / \mathrm{ha})$ than nonattendants $(0.31 \mathrm{~kg} / \mathrm{ha})$ before the clinic. After the participation in clinic, it was found to decrease significantly to $0.04 \mathrm{~kg} / \mathrm{ha}$ but significantly increased to $0.43 \mathrm{~kg} / \mathrm{ha}$ among non-attendants. the study signifies the impact of plant clinics to minimize the use of herbicides. One the other hand, the average dose of pesticide used before the clinic was non-significantly higher among attendants $(0.41 \mathrm{~kg} / \mathrm{ha})$ than non-attendants $(0.47 \mathrm{~kg} / \mathrm{ha})$ but it was found to increased significantly by $0.23 \mathrm{~kg} / \mathrm{ha}$ among attendants while insignificantly by $0.11 \mathrm{~kg} / \mathrm{ha}$ among non-attendants.

The proportion of clinic attendants' using herbicides was decreased from $25 \%$ to $21 \%$ with dose of less than one $\mathrm{kg} / \mathrm{ha}$. On the other hand, the proportion of non-attendants using herbicide were found to increase from $30 \%$ to $39 \%$ where $17 \%$ farmers were using more than one $\mathrm{kg}$ herbicides per hectare. Figure 2 compares the proportion of attendants and non-attendants' farmers with herbicide dose category.

Similarly, this study found only $33 \%$ of clinic attending and $34 \%$ of the non-attending farmers were using chemical pesticides before the clinic which has increased by $9 \%$ among attendants and 3\% among non-attendants. The details of the frequency of the farmers using different dose of pesticides is presented in figure 3 . This increment among attendants obvious because they should have visited the clinic with their problems where the plant doctors recommended pesticides either organic or inorganic (combined here) against the problem and farmers used it but the non-attendants might not care about the plant health problems or take other action. On the other hand, if we consider the total amount of agrochemical use - it is lower among attendants than non-attendants which indicates the judicious use of chemical as advised by experts aiming for better harvest. 

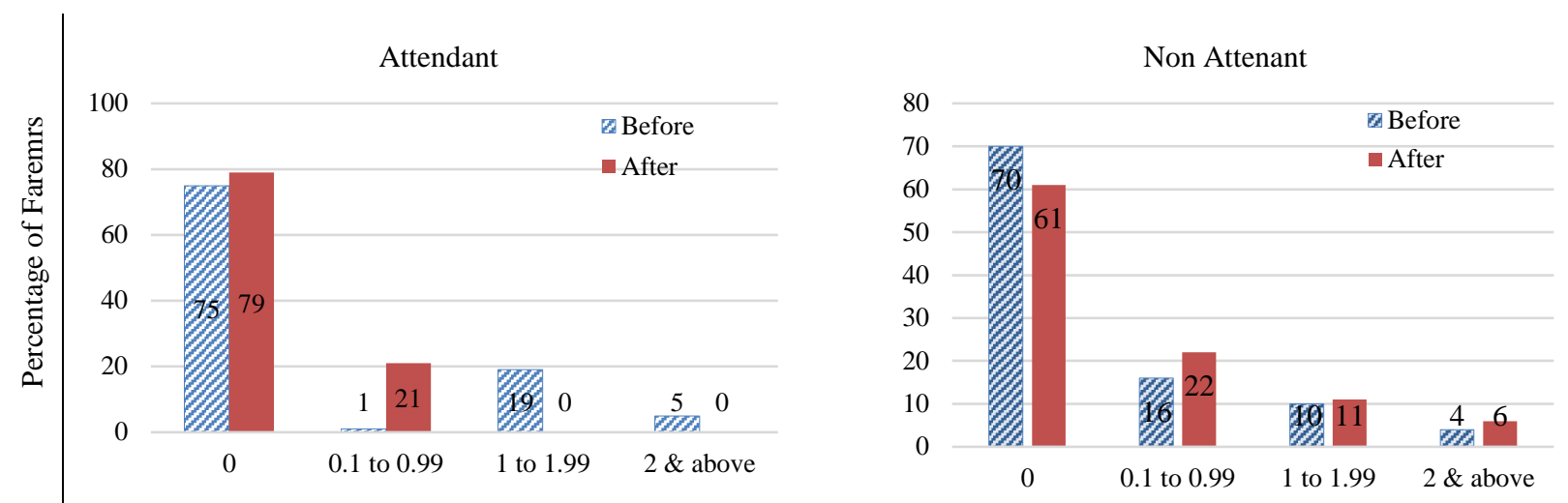

Category by dose $(\mathrm{Kg} / \mathrm{ha})$

Figure 2 Proportion of farmers using different doses of herbicides
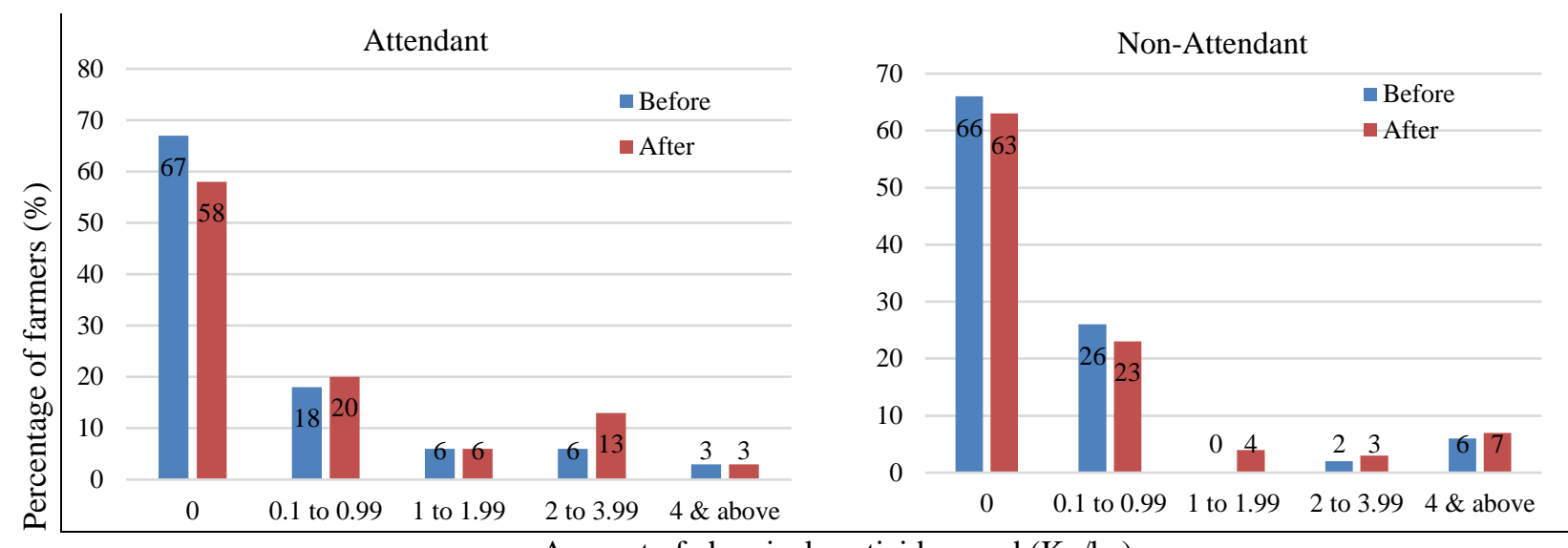

Amount of chemical pesticides used $(\mathrm{Kg} / \mathrm{ha})$

Figure 3 Proportion of farmers using different doses of chemical pesticides

Pesticide Dose Recommendation and Adoption

Knowledge and adoption of recommended dose of pesticides is another important factor for profitable and sustainable farming system. Before the clinic period, $29.7 \%$ of the attendant and $26.9 \%$ of the non-attendant were knowledgeable on recommended doses of pesticides but it was found to be increased to $75.4 \%$ and $52.6 \%$ among attendant and non-attendants respectively after the clinics. This difference in difference by almost $20 \%$ is meaningful both form economic and environmental perspectives.

The study found notable changes in farmer's knowledge on appropriate method of pesticide applications. During the pre-clinic period, only $42.9 \%$ of the attendant and $41.1 \%$ of the non-attendant were knowledgeable on appropriate method of pesticide application. But, during the post-clinic period, $85.7 \%$ of attendant and $64.0 \%$ non-attendant were found to be familiar in appropriate method of pesticide application (table 6). The net difference in difference of $19.9 \%$ on proportion of respondent is the impact of plant clinics.

The study found the positive impact not only on knowledge but also on practice of using chemical pesticides. Table 5 describes the positive changes on adoption of recommended dose of pesticides and the changes was impressive among attendants. Before the clinic period, the proportion of farmers always adopting the recommended dose of pesticides were only $13.1 \%$ among attendants and $8.6 \%$ among non-attendants but after the clinics, it was found to be increased by $37.8 \%$ and farmers among attendant and but only $10.8 \%$ among clinic nonattendants. This net difference of $20 \%$ indicates the highly positive influence of plant clinics on adoption of recommended dose of pesticides while curing their crop health. Another study done in Bangladesh revealed that $97 \%$ of the clinic users fully implemented the advice recommended by the plant doctors (Rajendran and Islam, 2017).

The study also found $31.4 \%$ of attendants and $27.4 \%$ of non-attendant respondents were knowledgeable on organic measures against pest and diseases before the clinic. But, after the clinic $64.6 \%$ of clinic attendants were found knowledgeable on organic measures whereas only $36 \%$ of non-attendant were found knowledgeable on this.

\section{Waiting Period}

The study found notably greater positive changes in knowledge and practice on waiting period among clinic attendants than non-attendants (table 6). The study found $16 \%$ of the clinic attendant and $19.4 \%$ of the non-attendant respondents were not aware about the waiting period after use chemical pesticides. But after the clinic, this proportion has sharply declined to $2.3 \%$ among attendants but still $13.1 \%$ among non-attendants. There were $21.7 \%$ attendants and $23.4 \%$ non-attendants were found not caring about the waiting period before the clinic that has dropped to zero among attendants while still $10.3 \%$ non-attendants were found not caring about it. 
Table 6 Change in adoption of recommended dose of pesticides

\begin{tabular}{|c|c|c|c|c|c|}
\hline \multirow{3}{*}{ KAP Parameters } & \multicolumn{4}{|c|}{ Percentage of farmers by category } & \multirow{3}{*}{$\begin{array}{l}\text { Difference in Difference } \\
\text { (DiD) }\end{array}$} \\
\hline & Attenc & & Non-Att & dant & \\
\hline & \multicolumn{4}{|c|}{ BeforeAfterDifferenceBeforeAfterDifference } & \\
\hline Knowledge on recommended dose of pesticides & 29.775 .4 & 45.7 & 26.952 .6 & 25.7 & 20 \\
\hline Knowledge on methods of pesticide use & $42.9 \quad 85.7$ & 42.8 & $41.1 \quad 64.0$ & 22.9 & 19.9 \\
\hline \multirow{3}{*}{$\begin{array}{l}\text { Adoption of recommended dose of } \\
\text { pesticides }\end{array}$} & 13.150 .9 & 37.8 & $\begin{array}{ll}8.6 & 19.4\end{array}$ & 10.8 & 27 \\
\hline & 7.420 .0 & 12.6 & 22.3 & 18.3 & -5.7 \\
\hline & 4.6 & -4.5 & 14.310 .9 & -3.4 & 1.1 \\
\hline Knowledge on organic measures & $31.4 \quad 64.6$ & 33.2 & $27.4 \quad 36.0$ & 8.6 & 24.6 \\
\hline
\end{tabular}

Table 7 Practice of adopting waiting period after application of pesticides

\begin{tabular}{|c|c|c|c|c|c|c|c|}
\hline \multirow{3}{*}{ Practice of Waiting Period } & \multicolumn{6}{|c|}{ Percentage of farmers by category } & \multirow{3}{*}{$\begin{array}{c}\text { Difference in } \\
\text { Difference (DiD) }\end{array}$} \\
\hline & \multicolumn{3}{|c|}{ Attendant } & \multicolumn{3}{|c|}{ Non-Attendant } & \\
\hline & Before & After & Difference & Before & After & Difference & \\
\hline Not aware & 16.0 & 2.3 & -13.7 & 19.4 & 13.1 & -6.3 & 6.4 \\
\hline Rarely & 20.6 & 23.4 & 2.8 & 21.1 & 31.4 & 10.3 & -7.5 \\
\hline Mostly & 17.1 & 41.1 & 24 & 17.1 & 21.7 & 4.6 & 19.4 \\
\hline Always & 24.6 & 33.1 & 8.5 & 18.9 & 23.4 & 4.5 & 4 \\
\hline Don't care & 21.7 & 0.0 & -21.7 & 23.4 & 10.3 & -13.1 & 8.6 \\
\hline
\end{tabular}

\section{Conclusion}

Modernization in agriculture extension is vital to provide quality extension service with easy access to smallholder farmers to increase the global food production. Plant clinics, as innovation in extension system, performs important role largely by providing diagnostic and advisory services that are essentially unavailable elsewhere easily and has direct impact on farmers' knowledge, attitude and practice to tackle wide range of problems in their farming. The results of this study, particular the difference in difference (DiD) showed wider and positive changes among clinic attendants than non-attendants on insect, pest and disease identification. The study found net increment of $11.4 \%$ higher among attendants with knowledge on season of disease pest occurrence while $20.5 \%$ on economic threshold level of pest and diseases. The higher increment of among attendants who are knowledgeable on preventive measures $(30.8 \%)$ and curative measures $(26.3 \%)$ are clear indicator of impact of plant clinic on farmer's knowledge and attitudes. The significant increase in pesticide use and significant decrease in herbicide use illustrates the impact of plant clinic on judicious use of agro-chemicals by the attendants than non-attendants. It should also be considered together with use of recommended dose and cost incurred in relation to incremental yield.

\section{References}

Adhikari RK, Regmi PP, Thapa RB, GC YD, Boa E. 2015. SWOT Analysis of Plant Clinics in Nepal. IAAS J., 32:10218. Adhikari RK. 2012. Review of Plant Clinics in Nepal: 2008-2011. CABI, UK.

Adhikari RK. 2009. Plant health clinic initiatives in Nepal. SECARD Nepal and DADO Kathmandu, Nepal.

Adhikari RK, Regmi PP, Boa E, GC YD, Thapa RB. 2013. Innovation in plant health extension services: the case of plant clinics in Nepal. Econ. AGRO-Aliment. 15:235-245.

Adhikari RK, Regmi PP, Thapa RB, GC YD, Boa E. 2016. Determinants of farmers' participation in plant health clinics in Nepal. Nepal. J. Agric. Sci. 14:290-299.

Atreya K. 2005. Health cost of pesticide use in a vegetable growing area, central mid hills, Nepal. Himal. J. Sci. 3:8184. DOI: $10.3126 /$ hjs.v3i5.466
Bamberger M, Rugh J, Church M, Fort L. 2004. Shoestring Evaluation: Designing Impact Evaluations under Budget, Time and Data Constraints. Am. J. Eval. 25:5-37. DOI: 10.1177/109821400402500102

Bentley JW, Boa E, Danielsen S, Zakaria AKM. 2007. Plant clinics for healthy crops. LEISA Mag. 23:16-17.

Bertrand M, Duflo E, Mullainathan S. 2004. How Much Should We Trust Differences-In-Differences Estimates? Q. J. Econ. 119:249-275. DOI: 10.1162/003355304772839588

Bhurtyal YB, Kanbargi R, Shrestha U, Dhungana S, Poudel S. 2016. Knowledge, practice and use of pesticides among commercial vegetable growers of Kaski district, Nepal. Int. J. Sci. Technol. Eng. 3:196-200.

Boa E. 2009. How the Global Plant Clinic began? Outlooks Pest Manag. 20:112-116.

Boa E, Harling R. 2008. Starting plant health clinics in Nepal. Global Plant Clinic-CABI, UK.

CBS. 2014. Central Bureau of Statistics, National population and housing census 2011: Chitwan. Kathmandu, Nepal.

Chen S, Mu R, Ravallion M. 2006. Are there lasting impacts of aid to poor areas? Evidence from rural China (No. 4084), Policy Research Working Paper Series. The World Bank, Washington, D.C.

Cornhiel SL. 2006. Feminization of agriculture: trends and driving forces (No. 41367). The World Bank, Washington, D.C. Danielsen S, Fernandez M. (Eds.) 2008. Public plant health services for all.

Danielsen S, Kelly P. 2010. A novel approach to quality assessment of plant health clinics. Int. J. Agric. Sustain. 8:257-269. DOI: 10.3763/ijas.2010.0494

European Commission. 2005. Monitoring of Pesticides Residues in Products of Plant Origin in the European Union. Norway.

Gartaula HN, Visser LE, Niehof A. 2010. Feminisation of agriculture as an effect of male out-migration: unexpected outcomes from Jhapa District, Eastern Nepal. Int. J. Interdiscip. Soc. Sci. 5:565-578.

Gertler PJ, Martinez S, Premand P, Rawlings LB, Vermeersch CM. 2011. Impact Evaluation in Practice. The World Bank, Washington, D.C

Janhong K, Lohachit C, Butraporn P, Pansuwan P. 2005. Health promotion program for the safe use of pesticides in Thai farmers. Southeast Asian J. Trop. Med. Public Health 36 Suppl. 4:258-261. 
Jors E, Lander F, Huici O, Morant RC, Gulis G, Konradsen F. 2014. Do Bolivian small holder farmers improve and retain knowledge to reduce occupational pesticide poisonings after training on Integrated Pest Management? Environ. Health 13:75 DOI: 10.1186/1476-069X-13-75

KC GK, Pradhan D, Upadhyay BP, Upadhyay S. 2003. Sharing country agricultural extension experiences, challenges and opportunities. Regional workshop on operationalizing agricultural extension reforms in South Asia, New Delhi, India.

Kelly P, Bentley J, Rashid H, Zakaria AKM, Nuruzzamn M. 2008. Plant clinics help curb pesticides use in Bangladesh. Pestic. News 81:16-17.

Kroschel J, Alcazar J, Poma P. 2009. Potential of plastic barriers to control Andean potato weevil Premnotrypes suturicallus Kuschel. Crop Prot. 28:466-476. DOI: 10.1016/j.cropro. 2009.01.008

Launiala A. 2009. How much can a KAP survey tell us about people's knowledge, attitudes and practices? Some observations from medical anthropology research on malaria in pregnancy in Malawi. Anthropol. Matters 11(1). Available from: https://www.anthropologymatters.com/index.php /anth_matters/article/view/31/53 [15/07/2017]

Maharjan A, Bauer S, Knerr B. 2012. Do Rural Women Who Stay Behind Benefit from Male Out-migration? A Case Study in the Hills of Nepal. Gend. Technol. Dev. 16:95-123. DOI: $10.1177 / 097185241101600105$

Miiro R, Williams R, Kizauzi T. 2015. Gender Responsiveness in Plant Clinic Delivery. Listening to the Silent Patient Uganda's Journey towards Institutionalizing Inclusive Plant Health Services, CABI Working Paper. CABI, UK, p. 224.

Negussie KP, Day R, Romney D, Reeder R, Boa E, Muriithi C, Kamau R, Phiri N, Danielsen S, Murage N, Gitare I, Wanjiku R, Mutisya J, Ngige D, Kimani M, Festus W. 2011. Role of plant health clinics in meeting the needs of small-scale farmers for advisory services: experiences from Eastern Africa. International Conference on Innovations in Extension and Advisory Services: Linking Knowledge to Policy and Action for Food and Livelihoods, CTA, Nairobi, Kenya, p. 9.
Ngowi AV, Maeda DN, Partanen TJ. 2002. Knowledge, attitudes and practices (KAP) among agricultural extension workers concerning the reduction of the adverse impact of pesticides in agricultural areas in Tanzania. Med. Lav. 93:338-346.

Oerke EC. 2006. Crop losses to pests. J. Agric. Sci. 144:31-43. DOI: $10.1017 / \mathrm{S} 0021859605005708$

Rajendran G, Islam R. 2017. Plant Clinics in Bangladesh: Are Farmers Losing Less and Feeding More? CABI Case Study (19).

Ravallion M. 2005. Evaluating Anti-Poverty Programs. World Bank Policy Research Working Paper No. 3625. World Bank, New York.

Sarma PK, Raha SK, Jørgensen H, Mia MIA. 2016. Impact analysis of beef cattle agribusiness on income: A double difference approach. J. Bangladesh Agric. Univ. 13:109-115. DOI: $10.3329 /$ jbau.v13i1.28726

Shrestha PL, Neupane FP. 2002. Socio-economic context on pesticide use in Nepal. Landschaftsökologie Umweltforsch. 38:205-223.

Srivastava MP. 2013. Plant clinic towards plant health and food security. Int. J. Phytopathol. 2:193-203.

Stack JP, Thomas JE, Baldwin W, Verrier PJ. 2014. Virtual Diagnostic Networks: A Platform for Collaborative Diagnostics. In: Gullino ML, Bonants P. Detection and Diagnostics of Plant Pathogens. Plant Pathology in the 21st Century. vol 5. pp:147-156. Springer, Dordrecht. DOI: 10.1007/978-94-017-9020-8_10.

Vakilian KA. 2017. Using networks in plant disease diagnosis. CAB Rev. 12:1-12. Verner M, Verner D. 2013. Economic impacts of professional training in the informal sector: the case of the labor force training program in Cote d'Ivoire (No. 81307). The World Bank, New York.

WHO (World Health Organization). 2008. Advocacy, communication and social mobilization for TB control: a guide to developing knowledge, attitude and practice surveys. Switzerland. 